\title{
Death-feigning behaviour in Iphisa elegans: the second reported case in the Family Gymnophthalmidae (Reptilia: Squamata)
}

\author{
Paulo Roberto MACHADO-FILHO ${ }^{1 *}$, Guilherme Marson MOYA², Fábio MAFFEI ${ }^{3}$ \\ Universidade Estadual Paulista "Júlio de Mesquita Filho", Instituto de Biociências, Departamento de Zoologia, Av. 24-A, 1515, Bairro Bela Vista, Rio Claro, SP, Brazil \\ 2 Instituto Pró-Terra, Rua Nicolau Piragine, 253, Jaú, SP, Brazil \\ 3 Universidade Estadual Paulista, Faculdade de Ciências, Departamento de Ciências Biológicas, Avenida Engenheiro Luiz Edmundo Carrijo Coube, 14-01, Bauru, SP, Brazil \\ * Corresponding author: prmfilho.sbo@gmail.com
}

\begin{abstract}
Death-feigning behaviour occurs when the animal simulates a state of immobility. This behaviour is described for some lizard families, among them the family Gymnophthalmidae with only one record. Iphisa elegans is a diurnal and terrestrial Amazonian lizard, it has cryptic behavior and moves rapidly on the ground, hindering observations of its behavior. We report a case at the Comodoro Municipality, Mato Grosso State, Brazil: an adult male of I. elegans, when manipulated, turned its venter up and put itself in a death-feigning posture. This species is preyed by birds, snakes and other lizards s possibly behaving this way when the cryptic behaviour or scape attempt fails. More studies are necessary to observe the efficiency of this behaviour, as well as the frequency that it occurs, using individuals of both sexes. We also suggested to evaluate if the orange venter of males could have any antipredation advantage.
\end{abstract}

KEYWORDS: Reptiles, Ethology, Antipredator Display, Lizard, Thanatosis.

\section{Comportamento de tanatose em Iphisa elegans: o segundo caso na Família Gymnophthalmidae (Reptilia: Squamata)}

\section{RESUMO}

Fingir-se de morto é um comportamento no qual o animal simula um estado de imobilidade. Esse comportamento é descrito em algumas famílias de lagartos, dentre as quais, a família Gymnophthalmidae com apenas um registro. Iphisa elegans é um lagarto amazônico diurno e terrestre. Possui comportamento críptico e move-se rapidamente pelo solo, dificultando observaçóes de seu comportamento. Reportamos o primeiro caso no município de Comodoro, Estado do Mato Grosso, Brasil: um macho adulto de I. elegans, quando manipulado, virou seu ventre para cima e fingiu-se de morto. Esta espécie é predada por pássaros, serpentes e outros lagartos, possivelmente portando-se dessa forma quando o comportamento críptico ou tentativa de fuga falham. São necessários mais estudos para observar a eficiência desse comportamento, assim como a frequência de ocorrência, usando indivíduos de ambos os sexos. Também sugerimos que deve ser avaliado se a coloração alaranjada no ventre dos machos poderia fornecer alguma vantagem antipredação.

PALAVRAS-CHAVE: Répteis, Etologia, Comportamento Antipredação, Lagarto, Tanatose. 
Death-feigning behaviour (thanatosis) occurs when the animal simulates a state of immobility (i.e. pretending to be dead) in response to external stimuli (Santos et al. 2010). This behaviour could be effective against predators that do not feed on carrion or dead prey, and against those which need movement cues to find and handle further their prey (Toledo et al. 2011). For lizards, this behaviour is described for the families Crotaphytidae (Gluesing 1983), Dibamidae (Torres-Cervantes et al. 2004), Gymnophthalmidae (Muscat et al. 2016), Liolaemidae (Rocha 1993; Santos et al. 2010), Scincidae (Langkilde et al. 2003; Patel et al. 2016) and Tropiduridae (Galdino and Pereira 2002; Gomes et al. 2004; Kosldorf et al. 2004; Bertoluci et al. 2006).

The family Gymnophthalmidae is widely distributed from southern Mexico to Argentina, comprising more than 40 genera and 235 species, with 32 genera and 92 species being found in Brazil (Costa and Bérnils 2015; Uetz et al. 2017). Iphisa elegans is an small Amazonian Gymnophthalmidae, with mainly diurnal habits, found in leaf litter of Brazil, Bolivia, Colombia, Ecuador, Peru and the Guiana Shield (Guyana and Surinam) (Avila-Pires 1995; Andrade et al. 2013).

According to recent studies, the name Iphisa elegans includes a complex of cryptic species (Nunes et al. 2012). Adults of this species exhibit an antique-brown to dark yellowish dorsal surface, venter creamy grey in females and orange in males (Beebe 1945; Avila-Pires 1995). Such difference on the venter colour is characterized by sexual dichromatism (Rodrigues et al. 2007). These lizards have cryptic behavior, in which they run into the leaf litter whenever any disturbance happens around them (Hoogmoed 1973; Vitt et al. 2008). Due to the difficulty of observing specimens of I. elegans "in situ", their natural history and defensive repertoire are largely unknown. In order to enrich this knowledge for the family, we report the first case of death-feigning behaviour on the species and the second report for the whole Family Gymnophthalmidae.

On September $16^{\text {th }}, 2015$, three individuals of Iphisa elegans were captured in pitfall traps during a fauna monitoring program at Comodoro Municipality, Mato Grosso State, Brazil (13042'00.63”S 60²5'01.69”W). When manipulated, an adult male $(S V L=48 \mathrm{~mm}$, Figure 1$)$ turned venter up, putting itself in a death-feigning posture for 50 seconds. The same behaviour was repeated three times by the same individual, which held the position for about two minutes in each time. In all situations, the lizard kept its eyes closed, and only returned to the normal position when was put back onto the ground. The specimen is now housed at the Zoological Collection of the Universidade Federal de Goiás, municipality of Goiânia, Goiás State, Brazil (ZUFG 1221).

The first record for this behaviour in the family was for Placosoma glabellum, and the behaviour was similar to

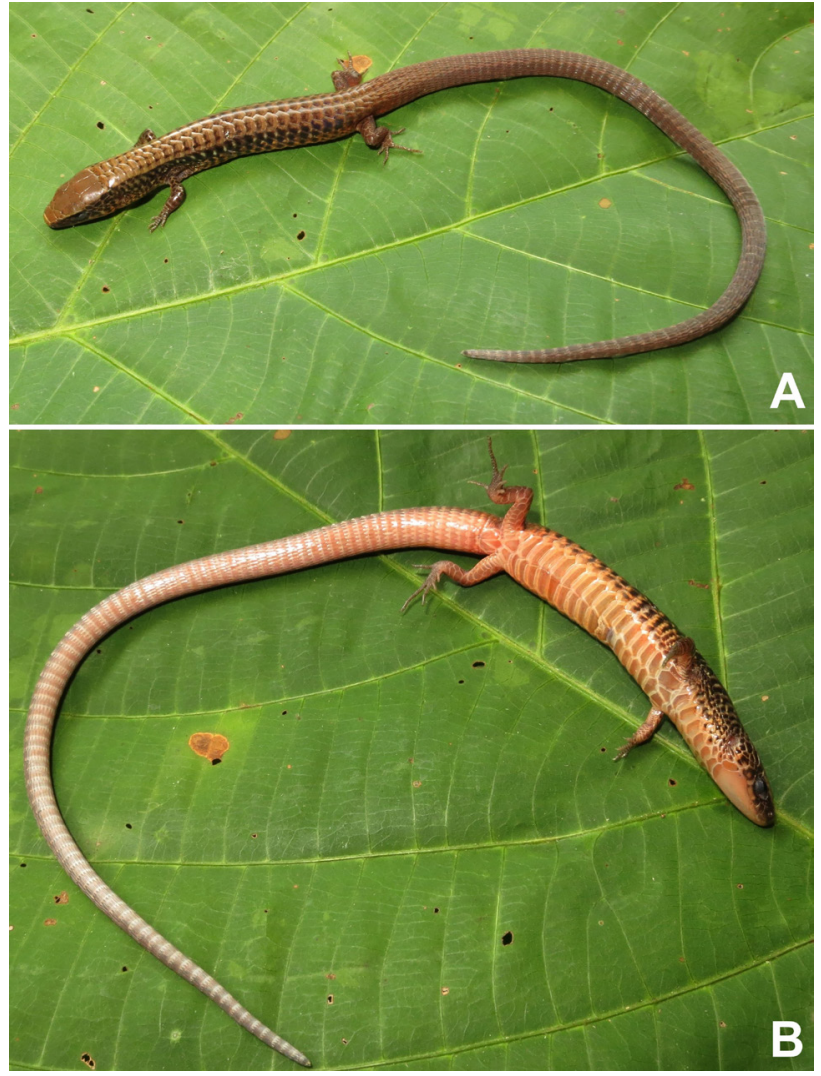

Figure 1. Individual of Iphisa elegans (ZUFG 1221, adult male): (A) In normal posture; (B) With exhibition of the orange venter. This figure is in colour only in the electronic version.

the case reported here. The lizard turned its venter up and remained still, with closed eyelids, maintaining this posture for approximately 60 seconds (Muscat et al. 2016).

Until now, all records of death-feigning behavior previously observed in lizards (with exception of an individual of Liolaemus lutzae and other of Lygosoma punctata), occurred after the specimens being stimulated, including our record (Gluesing 1983; Rocha 1993; Galdino and Pereira 2002; Langkilde et al. 2003; Gomes et al. 2004; Kosldorf et al. 2004; Torres-Cervantes et al. 2004; Bertoluci et al. 2006; Santos et al. 2010; Muscat et al. 2016; Patel et al. 2016).

Iphisa elegans is preyed by birds, lizards and snakes (Cunha 1961; Hoogmoed 1973; Duellman 1978; Prudente et al. 1998). It is possible that $I$. elegans uses the death-feigning posture when the cryptic behaviour or scape attempt failure. Besides, it is suggested that this behaviour could be used to confuse visual-orientated predators, such as birds. However, more studies are necessary to observe the efficiency of this behaviour, as well as the frequency that it occurs, using individuals of both sexes. In some species of lizards, the orange womb it may be related to hormonal cycles in breeding males (Cox et al. 2005). We also suggested to evaluate if the orange venter in males could have any antipredation advantage. 


\section{ACKNOWLEDGEMENTS}

We are grateful to Bruno G. Augusta, Paulo A. M. Goldoni, Rodrigo Castellari Gonzalez and the anonymous referees for suggestions and their critical reviews of the manuscript. We are also grateful to Instituto Brasileiro do Meio Ambiente e dos Recursos Naturais Renováveis by the License 617/2015 Process 02001.000328/2009-98 and Ambientare for financial and logistical support.

\section{REFERENCES}

Andrade, S.P.; Santos, D.L.; Kawashita-Ribeiro, R.A.; Vaz-Silva, W. 2013. New records and updated distribution map of Iphisa elegans Gray, 1851 (Reptilia, Gymnophthalmidae). Herpetology Notes, 6: 395-400.

Avila-Pires, T.C.S. 1995. Lizards of Brazilian Amazonia (Reptilia: Squamata). Zoologische Verhandelingen, 299: 1-706.

Beebe, W. 1945. Field notes on the lizards of Kartabo, British Guiana and Caripito, Venezuela. Part 3. Teiidae, Amphisbaenidae and Scincidae. Zoologica, 30: 7-31.

Bertoluci, J.; Cassimiro, J.; Rodrigues, M.T. 2006. TROPIDURIDAE (Tropidurid lizards). Death feigning. Herpetological Review, 37: 472-473.

Costa, H.C.; Bérnils, R.S. 2015. Répteis brasileiros: Lista de espécies 2015. Herpetologia Brasileira, 4: 75-93.

Cox, R.M.; Skelly, S.L.; Leo, A.; John-Alder, H.B. 2005. Testosterone regulates sexually dimorphic coloration in the eastern fence lizard, Sceloporus undulatus. Copeia. 2005:597-608.

Cunha, O.R. 1961. Lacertílios da Amazônia. II. Os lagartos da Amazônia brasileira, com especial referenda aos representados na coleção do Museu Goeldi. Boletim do Museu Paraense Emilio Goeldi, nova série Zoologia, 39:1-189.1.

Duellman, W.E. 1978. The biology of an Equatorial Herpetofauna in Amazonian Ecuador. Misc. Publ. Mus. Nat. Hist. Univ. Kansas, 65:1-352.

Galdino, C.A.B.; Pereira, E.G. 2002. Tropidurus nanuzae (NCN). Death feigning. Herpetological Review, 33: 54.

Gluesing, E.A. 1983. Collared lizard predation: the effects of conspicuous morphology and movement. Copeia, 1983: 835-837.

Gomes, F.R.; Kohlsdorf, T.; Navas, C.A. 2004. Thanatosis in Eurolophosaurus divaricatus: temperature and habituation effects. Amphibia-Reptilia, 25: 321-325.

Hoogmoed, M. S. 1973. Notes on the Herpetofauna of Surinam IV. The lizards and amphisbaenians of Surinam. Biogeographica 4, 1419 .
Kosldorf, T.; Rodrigues, M.T.; Navas, C.A. 2004. Eurolophosaurus divaricatus (NCN). Death feigning. Herpetological Review, 35: 390.

Langkilde, T.; Schwarzkopf, L.; Alford, R. 2003. An ethogram for adult male rainbow skinks, Carlia jarnoldae. Herpetological Journal, 13: 141-148.

Muscat, E.; Entiauspe-Neto, O.M.; Loebmann, D. 2016. Defensive behavior and predation on Placosoma glabellum (Peters, 1870) (Squamata: Gymnophthalmidae). Herpetologia Brasileira, 2: 51-52

Nunes, P.M.S.; Fouquet, A.; Curcio, F.F.; Kok, P.; Rodrigues, M.T. 2012. Cryptic species in Iphisa elegans Gray, 1851 (Squamata: Gymnophthalmidae) revealed by hemipenial morphology and molecular data. Zoological Journal of the Linnean Society, 166: 361-376.

Patel, H.; Naik, V.; Tank, S.K. 2016. Death-feigning behavior in two species of Lygosoma (Squamata: Scincidae) from India. Phyllomedusa, 15 (2): 191-194.

Prudente, A.L.C., Moura-Leite, J.C. de \& Morato, S.A.A. 1998. Alimentação das espécies de Siphlophis Fitzinger (serpentes, Colubridae, Xenodontinae, Pseudoboini). Revista Brasileira de Zoologia, 15: 375-383.

Rocha, C.F.D. 1993. The set of defense mechanisms in a tropical sand lizard (Liolaemus lutzae) of southeastern Brazil. Ciência e Cultura, 45: 116-122.

Rodrigues, M.T.; Pellegrino, K.C.M.; Dixo, M.; Verdade, V.K.; Pavan, D.; Argolo, A.J.S.; Sites, J.W. 2007. A new genus of microteiid lizard from the Atlantic Forests of state of Bahia, Brazil, with a new generic name for Colobosaura mentalis, and a discussion of relationships among the Heterodactylini (Squamata, Gymnophthalmidae). American Museum Novitates, 3565: 1-27.

Santos, M.B.; Oliveira, M.C.L.M.; Verrastro, L.; Tozetti, A.M. 2010. Playing dead to stay alive: thanatosis in Liolaemus occipitalis (Squamata: Liolaemidae). Biota Neotropica, 10: 361-364.

Toledo, L.F.; Sazima, I.; Haddad, C.F.B. 2011. Behavioural defenses of anurans: an overview. Ethology Ecology \& Evolution, 23: 1-25.

Torres-Cervantes, R.J.; Hernández-Ibarra, X.; Ramírez-Butista, A. 2004. Anelytropsis papillosus (Mexican Blind Lizard). Death feigning and autotomy. Herpetological Review, 35: 384.

Vitt, L.; Magnusson, W.E.; Ávila-Pires, T.C. \& Lima, A.P. 2008. Guide to the Lizards of Reserva Adolpho Ducke, Central Amazonia. Attema, Manaus, 180 pp.

Uetz, P; Freed, P.; Hošek, J. 2017. The Reptile Database. (http:// www.reptile-database.org). Acesso em 27/10/2016.

RECEIVED: $14 / 11 / 2017$

ACCEPTED: $31 / 12 / 2017$

ASSOCIATE EDITOR: Claudia Keller 